$=$ = NATURAL RESOURCES JOURNAL

Volume 31

Issue 4 Fall 1991

Fall 1991

\title{
The World Bank and the Environmental Challenge
}

Channing Kury

\section{Recommended Citation}

Channing Kury, The World Bank and the Environmental Challenge, 31 Nat. Resources J. 982 (1991).

Available at: https://digitalrepository.unm.edu/nrj/vol31/iss4/16

This Book Review is brought to you for free and open access by the Law Journals at UNM Digital Repository. It has been accepted for inclusion in Natural Resources Journal by an authorized editor of UNM Digital Repository. For more information, please contact amywinter@unm.edu, Isloane@salud.unm.edu, sarahrk@unm.edu. 


\title{
BOOK REVIEWS
}

\section{THE WORLD BANK AND THE ENVIRONMENTAL CHALLENGE}

\author{
PHILIPPE LE PRESTRE \\ Selinsgrove: Susquehanna University Press, 1989. Pp. 263.
}

Philippe Le Prestre's The World Bank and the Environmental Challenge is an excellent, although tedious, outline of the World Bank's response to the mandate that the environment is no longer to be ignored in the economics of developing nations. The mission of the World Bank has from the bank's creation at the end of World War II been to alleviate the poverty of many nations through development loans. Loan placement was predicated for many years upon traditional economic and engineering analyses that failed to incorporate not only the impact of a project on the environment but also the impact of the environment on development.

The bank began to change during the tenure of Robert McNamara as its president. Mr. McNamara appears to have recognized the problem and made significant if incremental steps toward the incorporation of environmental concerns into World Bank policy and practice. However, the World Bank is a bureaucracy that continued to be dominated by money managers, and its progress has been slow and halting. In recent years, the bank has been projecting its environmental concerns more prominently, although it is still a long way from fully implementing environmental wisdom into its actions.

Philippe Le Prestre is neither an environmental Jeremiah nor a bank apologist. His analysis is an appropriate starting point and a useful tool for persons seeking to understand such controversies as Brazil's POLONOROESTE settlement program. Although particular controversies are mentioned and a couple briefly discussed, this book is not a catalogue of environmental crises, but it is rather a critique of a bureaucracy as a bureaucracy. The tenor of the book is demonstrated by its leading off not with a colorful picture of a macaw or a quetzal, but with a list of acronyms used throughout the book. Of course, those persons who would save rainforests need to learn the ABC's of the World Bank just as much as those persons who would eradicate poverty. 